\title{
Process optimization for the rapid production of adenoviral vectors for clinical trials in a disposable bioreactor system
}

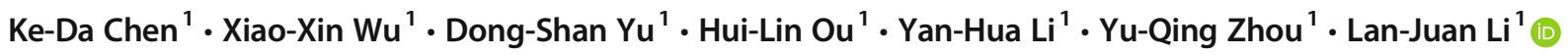

Received: 29 March 2018 / Revised: 9 May 2018 / Accepted: 10 May 2018 / Published online: 2 June 2018

(C) Springer-Verlag GmbH Germany, part of Springer Nature 2018

\begin{abstract}
Recombinant adenoviral (Ad) vectors are highly efficient gene transfer vectors widely used in vaccine development and immunotherapy. To promote the industrial application of Ad vectors, studies focusing on reducing the cost of manufacturing, shortening the preclinical research period, and improving the quality of products are needed. Here, we describe a highly efficient and economical process for producing Ad vector in a novel, single-use bioreactor system suitable for clinical trials. A mini-bioreactor was used for parameter optimization and development of medium replacement protocols for Ad5-GFP production before scaleup. HEK293 cell culture and virus infection were monitored in a disposable AmProtein Current Perfusion Bioreactor and Bioflo310 bioreactor using optimized parameters and medium replacement protocols. The total cell number increased from $2.0 \times 10^{9}$ to $3.2 \times 10^{10}$ after 6 days of culture. The total number of viral particles obtained in a single batch was $1.2 \times 10^{15}$. These results demonstrate the efficiency and suitability of this system for Ad vector production for research and GMP applications.
\end{abstract}

Keywords Adenoviral vector $\cdot$ Disposable bioreactor $\cdot$ HEK293 cells $\cdot$ Process optimization

\section{Introduction}

Recombinant adenovirus (Ad) vectors are highly efficient gene transfer vectors widely used in vaccine development and immunotherapy. Gendicine, an Ad-based gene therapy that delivers wild-type $\mathrm{p} 53$ for the treatment of head and neck squamous cell carcinoma, was the first Ad-based therapy approved by the State Food and Drug Administration (SFDA) in China (Guan et al. 2006; Zhang et al. 2018). The application of Ad vectors continues to expand worldwide due to several advantages over other vectors, including ease of vector construction, efficiency of the manufacturing process, and high vector stability (Lusky 2005; Sharon and Kamen 2018). To promote the industrial application of Ad vectors, future studies should focus on reducing the cost of manufacturing,

Ke-Da Chen and Xiao-Xin Wu contributed equally to this work.

Lan-Juan Li

1jli@zju.edu.cn

1 State Key Laboratory for Diagnosis and Treatment of Infectious Disease, Collaborative Innovative Center for Diagnosis and Treatment of Infectious Diseases, The First Affiliated Hospital, Zhejiang University School of Medicine, Hangzhou 310003, China shortening the preclinical research period, and improving product quality.

The HEK293 cell line is widely used to produce Ad vectors. There are several culture systems available for manufacturing including roller bottles, cell factories, cell cubes, and bioreactors (Kamen and Henry 2004; Lusky 2005). Of these systems, bioreactors hold many advantages over the others. AmProtein (Hangzhou, China) has developed a novel disposable bioreactor system that includes a miniature bioreactor for parameter evaluation before scale-up to a disposable perfusion bioreactor (AmProtein Current Perfusion Bioreactor [ACPB]) (Sun et al. 2013; Hui 2007; Qian et al. 2008; Li et al. 2009).

This bioreactor system provides good nutrient distribution and excellent oxygen transfer without gas bubbles and shearing forces, and is especially suitable for anchorage-dependent cell culture and virus production.

The production of Ad vectors in bioreactors has been extensively studied. Most research has focused on physicochemical operating conditions, including important parameters such as $\mathrm{pH}$, dissolved oxygen (DO) concentration, multiplicity of infection (MOI), temperature, and medium replacement strategies (Iyer et al. 1999; Jardon and Garnier 2003; Liu et al. 2009; Schoofs et al. 1998; Shen et al. 2012; Singh 1999; Sun et al. 2013; Hui 2007; Qian et al. 2008). The key to 
establishing a highly efficient productive system for Ad vectors is a detailed understanding of Ad biology, including the kinetics of replication in HEK293 cells and characteristics of cell metabolism during infection.

In this study, we describe a rapid process for Ad vector production from HEK293 cells cultured in a disposable bioreactor system. We also describe optimal parameters for $\mathrm{Ad}$ vector production. The purpose of this study is to reduce the duration of preclinical research and the cost of manufacturing for clinical trials and applications under good manufacturing practice (GMP) conditions.

\section{Material and methods}

\section{Cell lines and Ad vector}

HEK293 cells were purchased from American Type Culture Collection (ATCC; CL-1573) and cultured at $37{ }^{\circ} \mathrm{C}, 5 \% \mathrm{CO}_{2}$ in Dulbecco's Modified Eagle's medium (DMEM; Gibco, USA) supplemented with $10 \%$ fetal bovine serum (FBS; Gibco, USA) and $3.0 \mathrm{~g} / \mathrm{L} \mathrm{NaHCO}_{3}$. The Ad.MAX ${ }^{\mathrm{TM}}$ system (SignaGen Laboratories Inc., USA) was used to generate a $\Delta \mathrm{E} 1 / \Delta \mathrm{E} 3 \mathrm{Ad} 5$ vector expressing green fluorescence protein (GFP) under the control of the CMV promoter (Ad5-GFP) (Cote et al. 1997). We performed plaque purification to obtain clonal Ad (Green and Wold 1979). In brief, the viral stocks $\left(10^{2}, 10^{3}, 10^{4}, 10^{5} \mathrm{IU} / \mathrm{mL}\right)$ in $0.2 \mathrm{~mL}$ were applied to HEK293 cells grown in 6-well plate (Corning, USA). After $2 \mathrm{~h}$ postinfection at $37^{\circ} \mathrm{C}$, the inocula were removed and the plaque assays were performed using an agar overlay on HEK293 cells. Seventy-two hours post-infection, well-separated virus plaque was picked with sterile pipette. The agar plugs were transferred to microfuge tubes containing $0.5 \mathrm{~mL}$ DMEM. We picked five plaques and selected one plaque as the pre-master virus seed for further amplification. The remaining stocks were stored at $-70{ }^{\circ} \mathrm{C}$.

The cells often grow inside the carrier, not on the surface (Fig. 1d). Trypsin (Gibco, USA) digestion can easily detach the cells for scale up seeding without damage to the cells' viability. In brief, we washed the cell carrier contained in the minibioreactor and removed the cells by trypsinization $\left(37^{\circ} \mathrm{C}\right.$, $10 \mathrm{~min})$. We routinely removed $85 \%$ cells into the medium. A master cell bank $\left(8 \times 10^{6}\right.$ cells $/ \mathrm{mL}, 1.5 \mathrm{~mL} /$ vial, 143 vials $)$ and working cell bank $\left(6.5 \times 10^{6}\right.$ cells $/ \mathrm{mL}, 1.5 \mathrm{~mL} / \mathrm{vial}, 303$ vials) were generated by passage and propagation of HEK293 cells from T75 flasks to the mini-bioreactor (Table 1).

\section{Mini-bioreactor culture of HEK293 cells}

The mini-bioreactor system (AmProtein Inc., China) contains a self-rotating incubator and a $100-\mathrm{mL}$ vessel packed with $0.6 \mathrm{~g}$ of polymer fiber carrier (Fig. 1). The available area for cell growth in $0.6 \mathrm{~g}$ of polymer fiber carrier is $960 \mathrm{~cm}^{2}$. Different densities of HEK293 cells $\left(0.3 \times 10^{7}, 0.6 \times 10^{7}\right.$, $\left.0.9 \times 10^{7}, 1.2 \times 10^{7}\right)$ were seeded in the mini-bioreactors and incubated in the self-rotating incubator $\left(37{ }^{\circ} \mathrm{C}, 5 \% \mathrm{CO}_{2}\right.$, $45 \mathrm{rpm})$ to determine the optimal cell density for infection. Each cell density was tested in triplicate. The medium was changed at 24-h intervals. The concentration of glucose in the medium was assessed at 24-h intervals using a glucose assay kit (Sigma, USA). Cells were counted by crystal violet staining. The relationship between cell density and glucose consumption rate (GCR) was analyzed.

\section{Optimization of viral yield in the mini-bioreactor}

To determine the effect of MOI on Ad vector yields in this system, HEK293 cells cultured in mini-bioreactor vessels were infected with Ad vectors at different MOIs $(\mathrm{MOI}=1$, 10, 20, or 50). To determine the effect of temperature on Ad vector production, HEK293 cells cultured in mini-bioreactor vessels were infected with Ad vectors $(\mathrm{MOI}=20)$ at different temperatures $\left(32,33,34,35,36\right.$, or $\left.37^{\circ} \mathrm{C}\right)$. The cell-free supernatants were removed at $24-\mathrm{h}$ intervals. Intracellular virus samples were collected at $96 \mathrm{~h}$ post-infection (hpi). Cells underwent three freeze-thaw cycles followed by centrifugation at $700 \times g$ for $5 \mathrm{~min}$. Supernatants were stored at $70{ }^{\circ} \mathrm{C}$. The infectious viral particle units (IU) and total viral particles (VP) were measured.

In order to develop the most suitable medium supplementation scheme allowing for the earlier release of viral particles to the supernatant, we designed four different protocols for post-infection medium supplementation in mini-bioreactors. Lactalbumin hydrolysate (LH, GIBCO, Life Technologies, USA) was used as the medium supplement.

Protocol 1 (P1): Inoculate Ad in DMEM and incubate for $2 \mathrm{~h}$, then supplement with $10 \% \mathrm{FBS}$, and change the medium at 24 -h intervals. Harvest supernatants from 48 to $96 \mathrm{hpi}$ at 24-h intervals.

Protocol 2 (P2): Inoculate Ad in DMEM for $2 \mathrm{~h}$, then supplement with glucose $(2 \mathrm{~g} / \mathrm{L})$, and change the medium at 24-h intervals. Harvest supernatants from 48 to $96 \mathrm{hpi}$ at 24-h intervals.

Protocol 3 (P3): Inoculate Ad in DMEM for $2 \mathrm{~h}$, then supplement with $10 \% \mathrm{FBS}$, incubate for $24 \mathrm{~h}$, and then replace the medium with DMEM supplemented with glucose $(2 \mathrm{~g} / \mathrm{L})$ at 24 -h intervals. Harvest supernatants from 48 to 96 hpi at 24-h intervals.

Protocol 4 (P4): Inoculate Ad in DMEM for $2 \mathrm{~h}$, then supplement with $10 \%$ FBS, incubate for $24 \mathrm{~h}$, and then replace the medium with DMEM supplemented with different concentrations of $\operatorname{LH}(0.1,0.25,0.5,1 \%[w / v])$ and glucose $(2 \mathrm{~g} / \mathrm{L})$ at $24-\mathrm{h}$ intervals. Harvest supernatants from 48 to 96 hpi at 24-h intervals. 
Fig. 1 Illustration of the minibioreactor. a Self-rotating incubator with vessels. b Vessels packed with polymer fiber carrier $(0.6 \mathrm{~g} /$ vessel). c Photomicrograph (magnification $\times 200$ ) of polymer fiber carrier. d Photomicrograph (magnification $\times 500$ ) of polymer fiber carrier with HEK293 cells

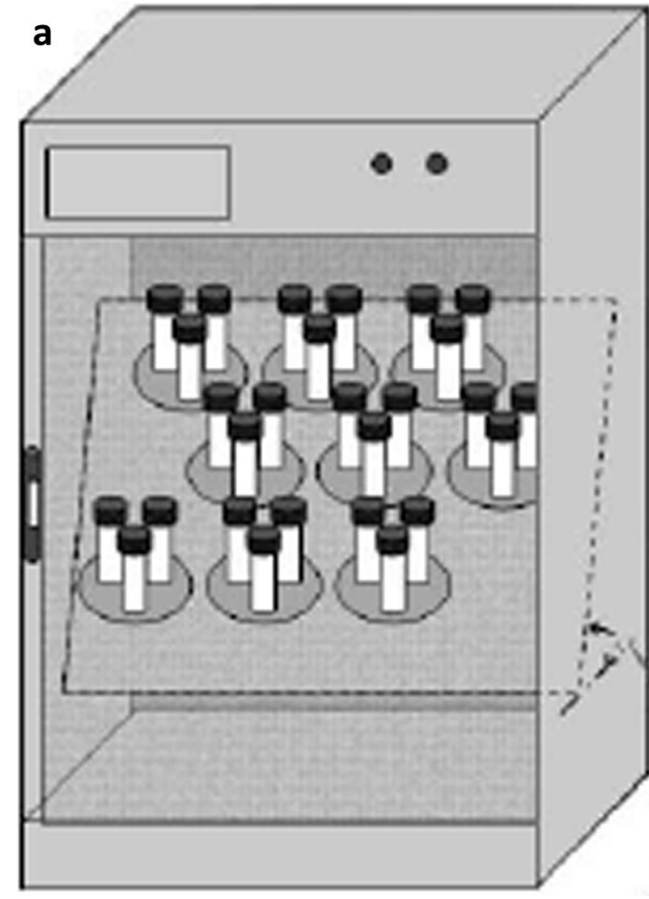

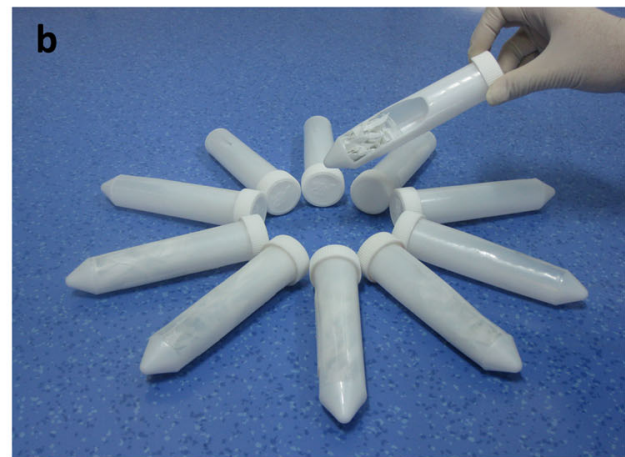
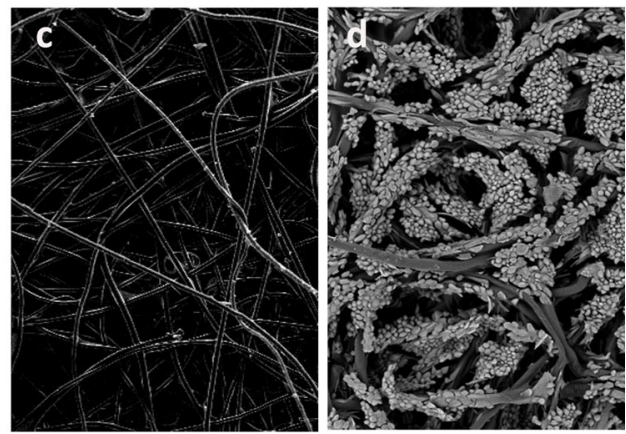

Each protocol was tested in triplicate, and the viral titers in the harvested supernatants determined. HiVegTM peptone (HiMedia Lab, India) was also tested, but the results were not worth pursuing (data not shown).

\section{Analysis of Ad vector}

IUs produced from the Ad vector were detected by rapid $\mathrm{TCID}_{50}$ assay [19] using a QuickTiter ${ }^{\mathrm{TM}}$ Adenovirus Titer Immunoassay Kit (Cell BioLabs, USA). Briefly, HEK293 cells were seeded at a density of $4 \times 10^{4}$ cells $/ 100 \mu \mathrm{L}$ onto 96-well plates. A series of 1:10 vector dilutions $\left(10^{5}-10^{12}\right)$ was added to each of 10 replicate wells for each dilution. The supernatant was discarded at 4 days post-infection, and the monolayers were fixed with $75 \%$ acetone. The cell monolayers were then incubated with anti-hexon $\mathrm{mAb}$ for $1 \mathrm{~h}$ at $37^{\circ} \mathrm{C}$, followed by a goat anti-mouse horseradish peroxidase conjugated secondary antibody for $1 \mathrm{~h}$ at $37^{\circ} \mathrm{C}$. Positive cells were counted and viral titers calculated.

Total viral particle (VP) determination was performed by a quick, high-performance liquid chromatography (HPLC) method as described by Whitfield et al. (2009). In brief,

Table 1 The seed train process developed for the bioreactor

\begin{tabular}{lll}
\hline Culture vessel & Total cells & Days of culture \\
\hline T75 flask & $1.8 \times 10^{7}$ & 4 \\
T75-2× mini bioreactor & $1.8 \times 10^{8}$ & 5 \\
$2 \times-25 \times$ mini bioreactor & $2.25 \times 10^{9}$ & 5 \\
$5-10$-L bioreactor & $2.8 \times 10^{10}$ & 6 \\
\hline
\end{tabular}

supernatants were filtered through a $0.45-\mu \mathrm{m}$ filter. An aliquot of the filtered supernatant was then analyzed on a Dionex DX500 Chromatography System (Dionex Corp., Sunnyvale, CA) using an anion exchange Bio-Monolith QA HPLC column (Agilent technologies; Santa Clara, CA). Analysis of UV data was performed using Chromeleon 6.80 (Dionex) and PeakSimple 3.85 (SRI Instruments, Torrance, CA).

\section{Virus production in ACPB and NBS-Bioflo310 bioreactors}

The ACPB system is a disposable bioreactor developed by Amprotein based on the world patent (Hui 2007). An illustration of the ACPB system is shown in Fig. 2. Phosphatebuffered saline (PBS; $10 \mathrm{mM}, 6 \mathrm{~L}$ ) was pumped into the disposable perfusion column (with $150 \mathrm{~g}$ polymer fiber carriers) and plastic bioreactor bag overnight, and then was replaced by $5 \mathrm{~L}$ DMEM. A total of $2.25 \times 10^{9}$ cells from 20 mini-bioreactors $\left(0.9 \times 10^{8}\right.$ cells $\times 150 \mathrm{~g} / 0.6 \mathrm{~g}=$ $2.25 \times 10^{9}$ ) were transferred into the perfusion column by feed bottle and incubated for $2 \mathrm{~h}$ without rocking. The physical parameters were set on the ACPB prior to rocking (temperature $37{ }^{\circ} \mathrm{C}$; rocking rate $50 \mathrm{rpm}$; $\mathrm{pH}$ 7.2-7.4; DO $50 \%-70 \%$; circulation rate $150 \mathrm{~mL} / \mathrm{min}$ ). The 5 -L medium was replaced at 24-h intervals, and the glucose levels were consistently maintained above $1.2 \mathrm{mg} / \mathrm{mL}$. After 5 days of culture, the cells were removed with polymer fiber carriers and divided into six parts. The concentration of the six parts and the total number of cells were determined using crystal violet staining (Fig. 3a). 


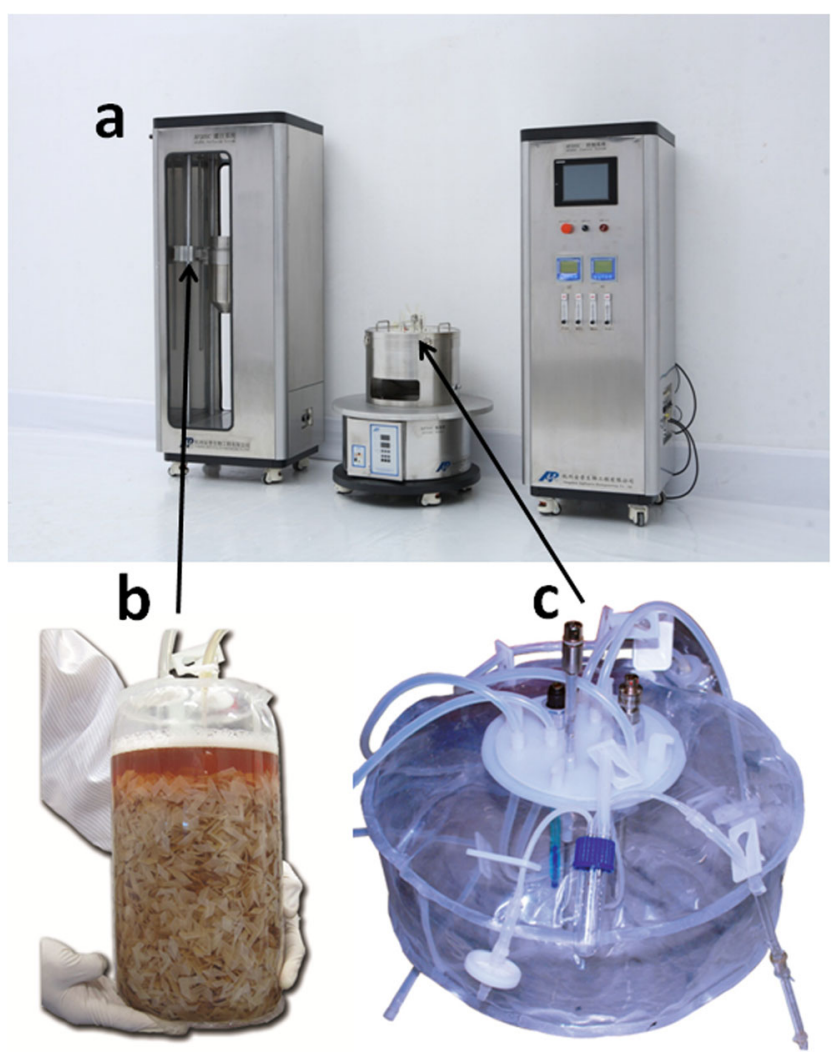

Fig. 2 Illustration of the ACPB system. a AmProtein Current Perfusion Bioreactor AP20SC. b Disposable 5-L plastic perfusion column with 150 -g polymer fiber carriers. c Disposable 10-L plastic bag with DO, $\mathrm{pH}$, and temperature probes

Ad5 vector propagation After 5 days of culture, the ACPB was washed twice with PBS. Ad vector $(\mathrm{MOI}=20)$ in $4 \mathrm{~L}$ fresh DMEM without FBS was pumped into the perfusion column and incubated for $2 \mathrm{~h}$, and an additional $5 \mathrm{~L}$ DMEM was pumped into the plastic bioreactor bag. The operating conditions for Ad vector propagation were set based on the results of the mini-bioreactor cultures: temperature of $33{ }^{\circ} \mathrm{C}$, vibrating rate of $50 \mathrm{rpm}, \mathrm{pH}$ of $7.2-7.4$, and $\mathrm{DO}$ of $55 \%$. The circulation rate was maintained at $120 \mathrm{~mL} / \mathrm{min}$. During the process, $5 \mathrm{~L}$ of the supernatant was harvested at 48 and $72 \mathrm{hpi}$ and the remaining $10 \mathrm{~L}$ was harvested at $96 \mathrm{hpi}$, for $20 \mathrm{~L}$ in total. The media was replaced with $5 \mathrm{~L} \mathrm{PBS}$, and the infected cells remaining on the polymer fiber carrier were subjected to three free-thaw cycles.

Bioflo310 is a bioreactor similar to ACPB that uses nonwoven polymer fiber paper as a cell carrier. It differs from $\mathrm{ACPB}$ in its structure (non-disposable) and operating procedures. During virus production, $4.5 \mathrm{~L}$ of medium was changed at 24 -h intervals. The 4.5 -L supernatants were harvested at 48 , 72 , and $96 \mathrm{hpi}$ (13.5 L in total). The media was replaced with 4 L PBS, and the infected cells remaining on the polymer fiber carrier were subjected to three free-thaw cycles. We used the same set of parameters and culture strategies for both the NBS-bioflo310 and ACPB to produce Ad5 vector. a
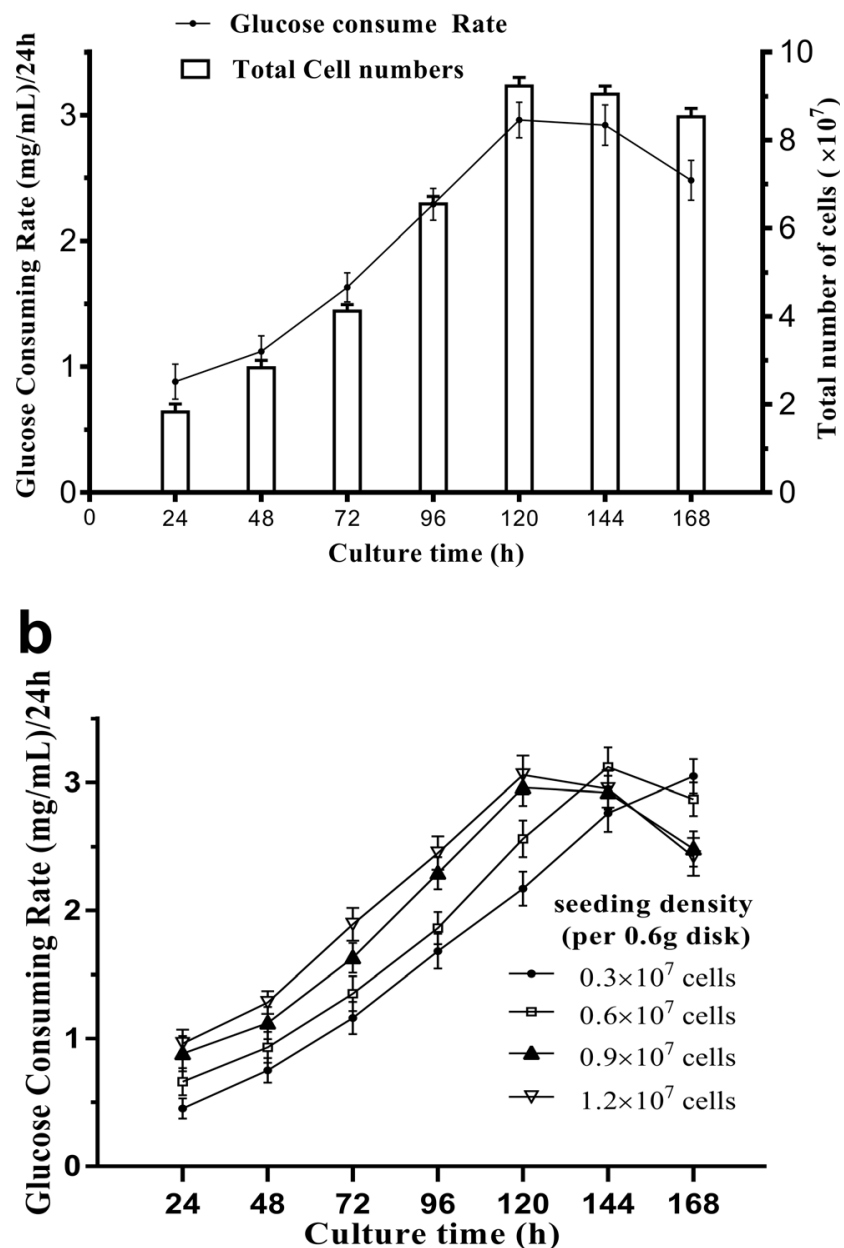

Fig. 3 Relationship between the glucose consumption rate (GCR) and total number of cells in the mini-bioreactor vessels. a Cell number is expressed as the number of cells per mini-bioreactor vessel, while GCR is expressed in milligrams per milliliter per 24-h interval in the minibioreactor vessel. b GCR at different seeding densities in the minibioreactor vessel

\section{Quality control of the Ad5 vector}

To further improve the quality of the product, we tested specific activity, i.e., the ratio of infectious virus particle units to the total number of virus particles (IU/VP). Currently, the Chinese SFDA requires that the specific activity of recombinant Ad clinical products must be greater than $3.3 \%$, which is 3.3 times higher than the $1 \%$ quality requirement stipulated in 1998. Residual BSA was detected using standard ELISA methods with a BSA-ELISA kit (Cygnus, USA).

To fully characterize the Ad5 product, a number of physical, chemical, and biological tests were also employed according to established guidelines and Chinese Phamacopoeia (2015), including Replication Competent Adenovirus (RCA) testing, sterility testing, endotoxin testing, and Adenoassociate virus (AAV) detection. RCA testing: The test samples were used to infect A549 cells. Four passages were 
performed and cells were regularly observed to detect cytopathic effect (CPE). Positive and negative controls were included to validate the assay. Sterility testing: Membrane-filter procedure was used in the test. After filtration, the membrane was incubated in two types of media (Soybean Casein Digest Broth, Fluid Thioglycollate Medium) for 14 days with intermittent observations during the testing period to detect evidence of microbial contamination. Endotoxin testing: The test samples were combined with Limulus amebocyte lysate reagent (FUJIFILM, US) and measuring the resulting proportional reaction by gel-clot. AAV detection: Viral DNA of the test samples were isolated using TRIzol reagent (Invitrogen, USA) according to the manufacturer's instructions. AAV was detected by PCR method using a pair of universal primers, forward primer $5^{\prime}$ AAC TGG ACC AAT GAA AAC TTT CC $3^{\prime}$ and reverse primer $5^{\prime}$ AAA AAG TCT TTG ACT TCC TGC TT $3^{\prime}$. Positive and negative controls are included to validate the assay.

\section{Results}

\section{Cell bank and virus seed generation and analysis}

A master cell bank $\left(8 \times 10^{6}\right.$ cells $/ \mathrm{mL}, 1.5 \mathrm{~mL} / \mathrm{vial}, 143$ vials $)$ and working cell bank $\left(6.5 \times 10^{6}\right.$ cells $/ \mathrm{mL}, 1.5 \mathrm{~mL} / \mathrm{vial}, 303$ vials) were generated. HEK293 cells were cultured over 20 passages to test their stability. The seed-train cultures were amplified using the different flasks and vessels listed in Table 1 . The master seeds (460 vials, $6.31 \times 10^{9} \mathrm{IU} / \mathrm{mL}$, $1 \mathrm{~mL} / \mathrm{vial}$ ) and working seeds of Ad vector (600 vials, $6.31 \times 10^{9} \mathrm{IU} / \mathrm{mL}, 1 \mathrm{~mL} /$ vial) were generated and analyzed (data not shown).

\section{Cell culture in mini-bioreactor vessels}

The GCR was determined based on the glucose concentration in fresh medium and the residual glucose concentration in the mini-bioreactor, measured at 24-h intervals. Cell growth and GCR profiles for HEK293 cells from the mini-bioreactor culture vessels are presented in Fig. 3a. Cell growth and GCR were positively correlated. The total cell number increased from $0.9 \times 10^{7}$ to $0.9 \times 10^{8}$ cells after 5 days of culture. The maximum GCR in the $30 \mathrm{~mL}$ system was $2.96 \mathrm{mg} / \mathrm{mL}$ between 96 and $120 \mathrm{~h}$ of culture. The maximum GCR was reached at different time points in accordance with the variation in cell seeding densities in the mini-bioreactor vessels (Fig. 3b). The seeding density of $0.9 \times 10^{7}$ cells per $0.6 \mathrm{~g}$ disk was considered to be the most appropriate for the culture time because the GCR was highly similar to the rate with the seeding density of $1.2 \times 10^{7}$ cells and reached the maximum value earlier than the other two density conditions.

\section{Optimization of viral yield in a mini-bioreactor}

We determined that the optimal seeding density was $0.9 \times 10^{7}$ cells per $0.6 \mathrm{~g}$ disk, and the optimal incubation time was 5 days. Next, we investigated the effects of different MOIs $(\mathrm{MOI}=1,10,20$, and 50$)$ on virus production in the minibioreactor. Following the infection with the Ad5 vector at $37{ }^{\circ} \mathrm{C}$, supernatants were harvested at 24 -h intervals and the viral titers determined by performing immunochemistry on HEK293 cells infected with Ad5 (Fig. 4a). Viral titers peaked at 96 hpi at MOIs of 1,10 , and 20, with lower titers obtained with MOIs of 1 and 10. At a MOI of 50, viral titers peaked at 72 hpi (Fig. 4b). Based on these results, we established that a MOI of 20 was the most appropriate MOI for this system.

The effects of temperature on virus production in the minibioreactor was also investigated. Supernatants were harvested at 24-h intervals and combined together from different harvest time (48, 72, and $96 \mathrm{hpi}$ ), and the viral titers (IU and VP) determined. We found that the viral titers were highest when the incubation temperature was $35^{\circ} \mathrm{C}$. The total harvest yield reached $1.0 \times 10^{8} \mathrm{IU}$ at a temperature of $35^{\circ} \mathrm{C}$ (Fig. $4 \mathrm{c}$ ).

\section{Effects of different medium supplements and culture strategies on viral yields}

To determine the most suitable medium supplementation for virus production, we tested four conditions: P1 (FBS), P2, P3, and P4 (LH). P4 contained four subgroups (LH 0.1, 0.25, 0.5, and $1 \%[w / v])$. The Ad was inoculated in the mini-bioreactors at an MOI of 20 and a temperature of $35^{\circ} \mathrm{C}$. The supernatants from the mini-bioreactors were harvested at 48,72 , and $96 \mathrm{hpi}$, and the viral titers were determined. The results of the viral yield revealed that $\mathrm{P} 1, \mathrm{P} 2$, and $\mathrm{P} 4(0.25 \% \mathrm{LH}$ and $0.5 \% \mathrm{LH})$ produced a higher titer than the other conditions, with the viral titers reaching 10.2, 9.6, 9.7, and $9.7 \log _{10} \mathrm{IU} / \mathrm{mL}$, respectively. P4 (0.25\% LH) and P4 (0.5\% LH) exhibited no differences in viral yield, indicating that P4 $(0.25 \% \mathrm{LH})$ may be the most suitable strategy in terms of the practical manufacturing of the Ad vector (Fig. 5).

\section{ACPB and NBS-Bioflo310 culture}

HEK293 cells from 10 mini-bioreactors $\left(2.25 \times 10^{9}\right.$ total cells) were seeded in the first ACPB culture run (ACPB-0). The cells were maintained under quiescent conditions for $2 \mathrm{~h}$ to allow for attachment. Approximately $97 \%$ of the seed cells attached during the 2-h quiescent period. The medium was replaced (5 L) at 24-h intervals, and the glucose levels were consistently maintained above $1.5 \mathrm{mg} / \mathrm{mL}$. After 6 days of culture, the total number of HEK293 cells was determined to be $2.8 \times 10^{10}$ by crystal violet staining of the fiber carriers obtained from the ACPB. The cell density at different positions was analyzed and suggested an even distribution pattern throughout the perfusion column (Fig. 6a). 
a
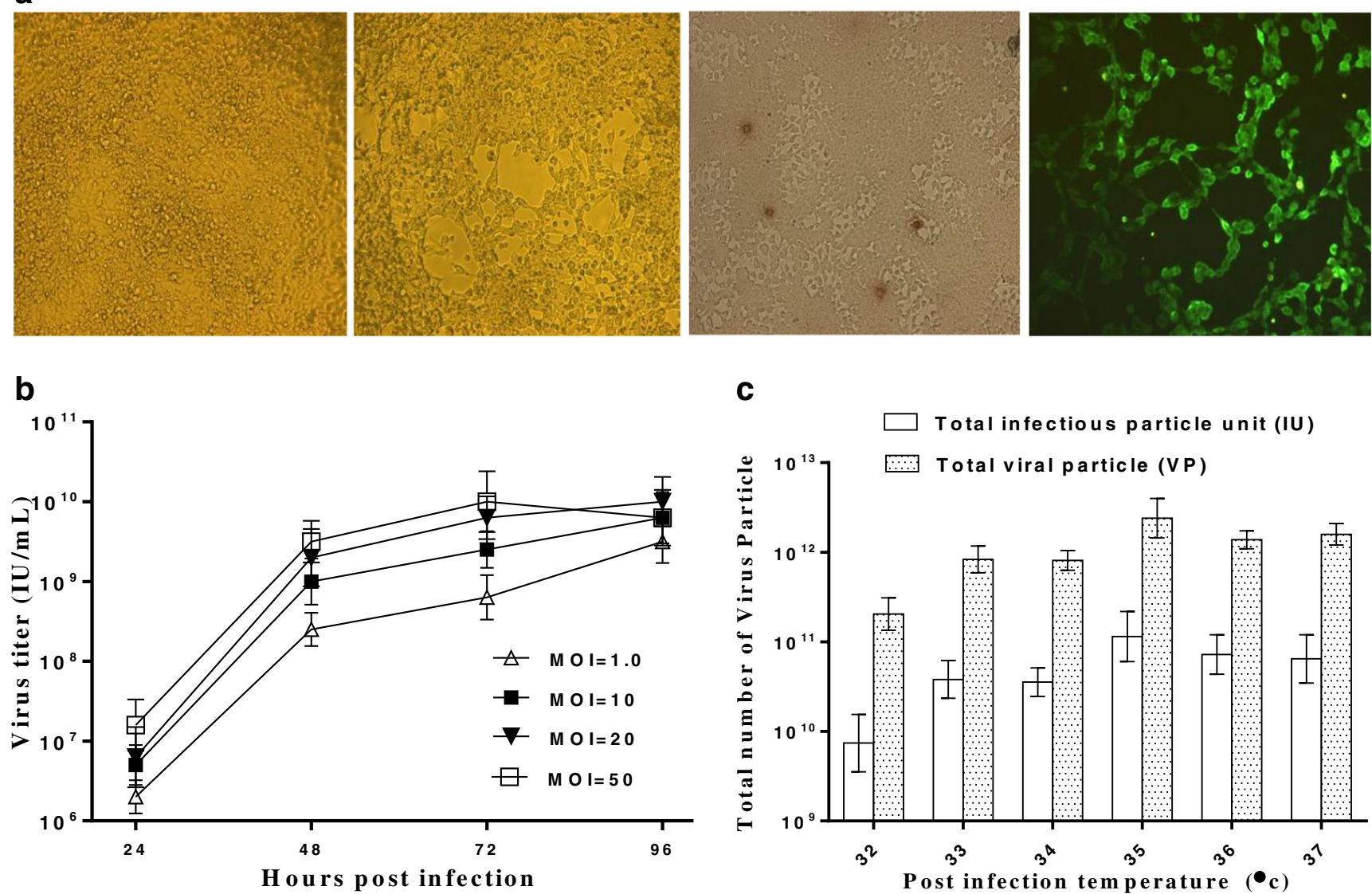

Fig. 4 Optimization of infection parameters in the mini-bioreactor. a Images of HEK293 cells infected with Ad5-GFP. Panel 1 control (uninfected), panel 2 plaque formation in infected cells, panel 3 immunochemical detection of Ad5 hexon protein, and panel 4 GFP

C

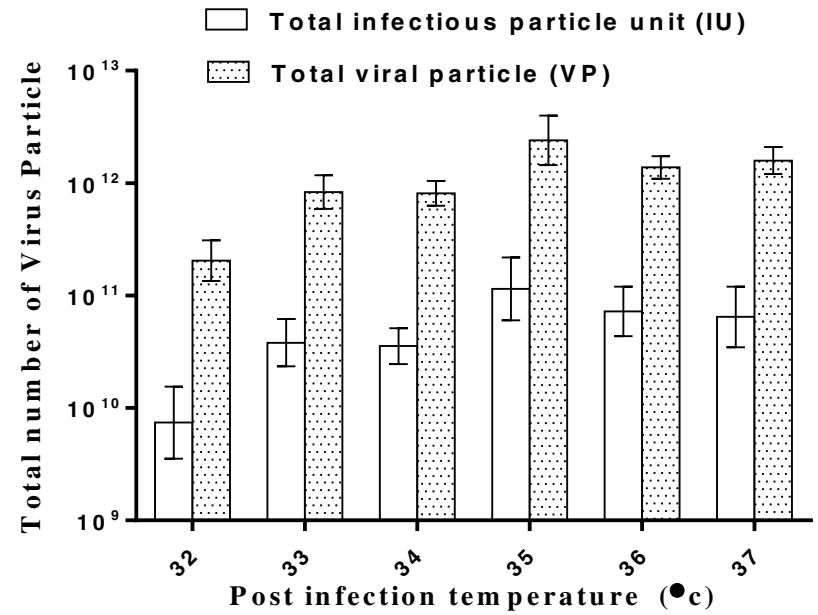

expression in infected cells detected by fluorescence microscopy. $\mathbf{b}$ Viral yields at different MOIs in the mini-bioreactor. $\mathbf{c}$ Total viral yields at different temperatures in the mini-bioreactor

titer at 48,72 , and 96 hpi were evaluated. The maximum viral titer reached was $9.8 \log _{10} \mathrm{IU} / \mathrm{mL}\left(8.8 \times 10^{9} \mathrm{IU} / \mathrm{mL}\right.$; Fig. $\left.6 \mathrm{c}\right)$. The total volume of the harvested supernatant was $20 \mathrm{~L}$, and the mean virus titer was $7.3 \times 10^{9} \mathrm{IU} / \mathrm{mL}$, with a total yield of $2.5 \times 10^{15} \mathrm{VP}$.

The final run was conducted on an NBS-Bioflo310 and used the P4 $(0.25 \% \mathrm{LH})$ strategy. The GCR at $24 \mathrm{~h}$ and the viral titer at 48, 72, and 96 hpi were evaluated. The maximum LH) strategy as described above. The GCR at $24 \mathrm{~h}$ and the viral
The second run (ACPB-1) used the P1 strategy as de$\log _{10} \mathrm{IU} / \mathrm{mL}$ (Fig. 6b). The total volume of vested supernatant was $20 \mathrm{~L}$, and the mean virus titer was $8.0 \times 10^{9} \mathrm{IU} / \mathrm{mL}$ with a total yield of $4.2 \times 10^{15} \mathrm{VP}$.
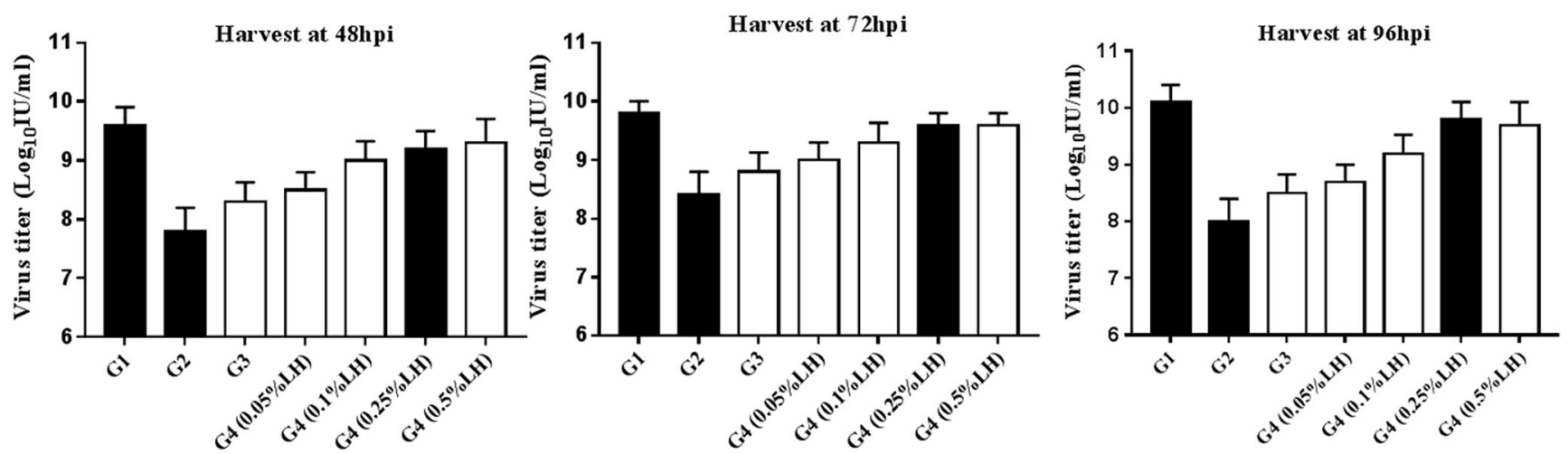

Fig. 5 Viral yields with different medium replacement strategies (P1-P4) and harvest times (48, 72, 96 hpi) 
a
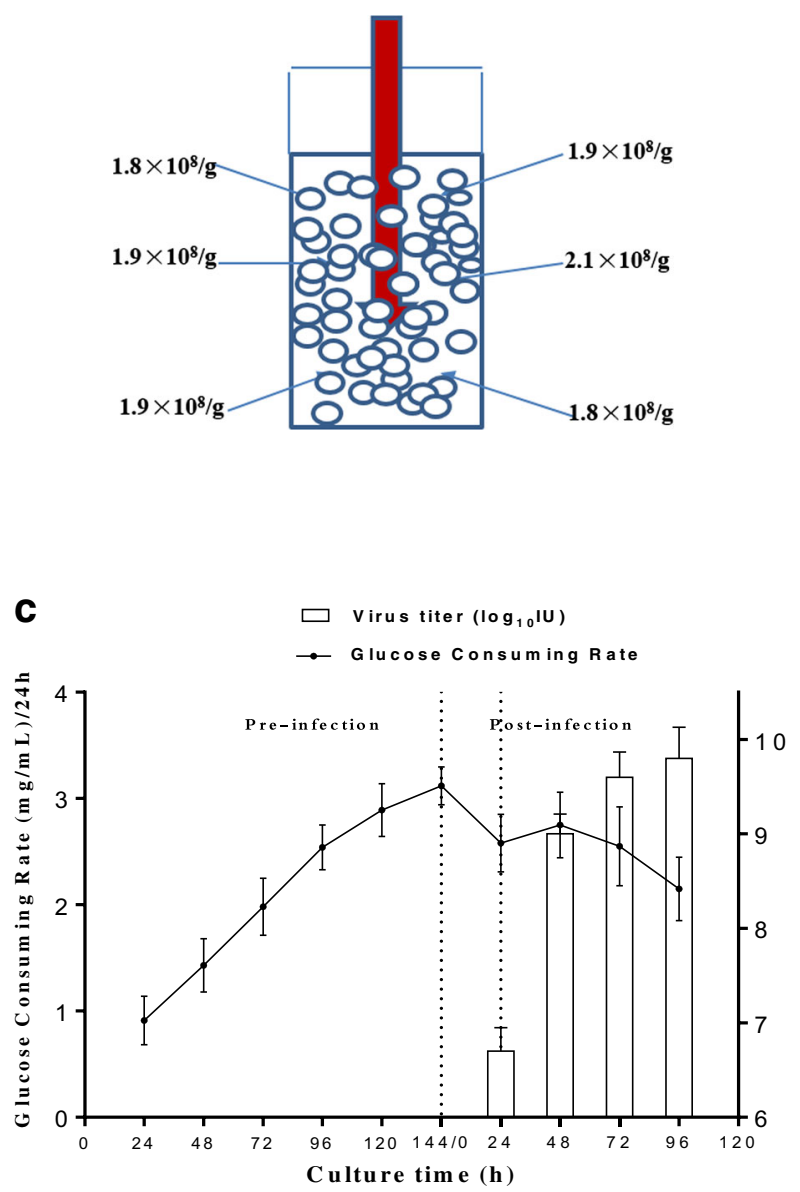

Fig. 6 ACPB and NBS-Bioflo310 cultures. a Cell distribution in a 5-L perfusion column filled with 150 -g polymer fiber carriers from the ACPB-0 run. b The GCR and viral titer in the ACPB-1 run using the

viral titer reached $10.0 \log _{10} \mathrm{IU} / \mathrm{mL}\left(1 \times 10^{10} \mathrm{IU} / \mathrm{mL}\right.$; Fig. $\left.6 \mathrm{~d}\right)$. The total volume of the harvested supernatant was $13.5 \mathrm{~L}$, and the mean virus titer was $8.1 \times 10^{9} \mathrm{IU} / \mathrm{mL}$, with a total yield of $1.8 \times 10^{15} \mathrm{VP}$.

The total yields (VP) harvested from supernatants (extracellular) and cell lysates (intracellular) were calculated. Approximately $40-60 \%$ of Ad5 vector remained in HEK293 cells (data not shown). Residual bovine serum albumin in supernatants harvested in 48,72 , and $96 \mathrm{hpi}$ from the ACPB and NBS-Bioflo310 was measured. The results show a large decrease in BSA using the P4 $(0.25 \%$
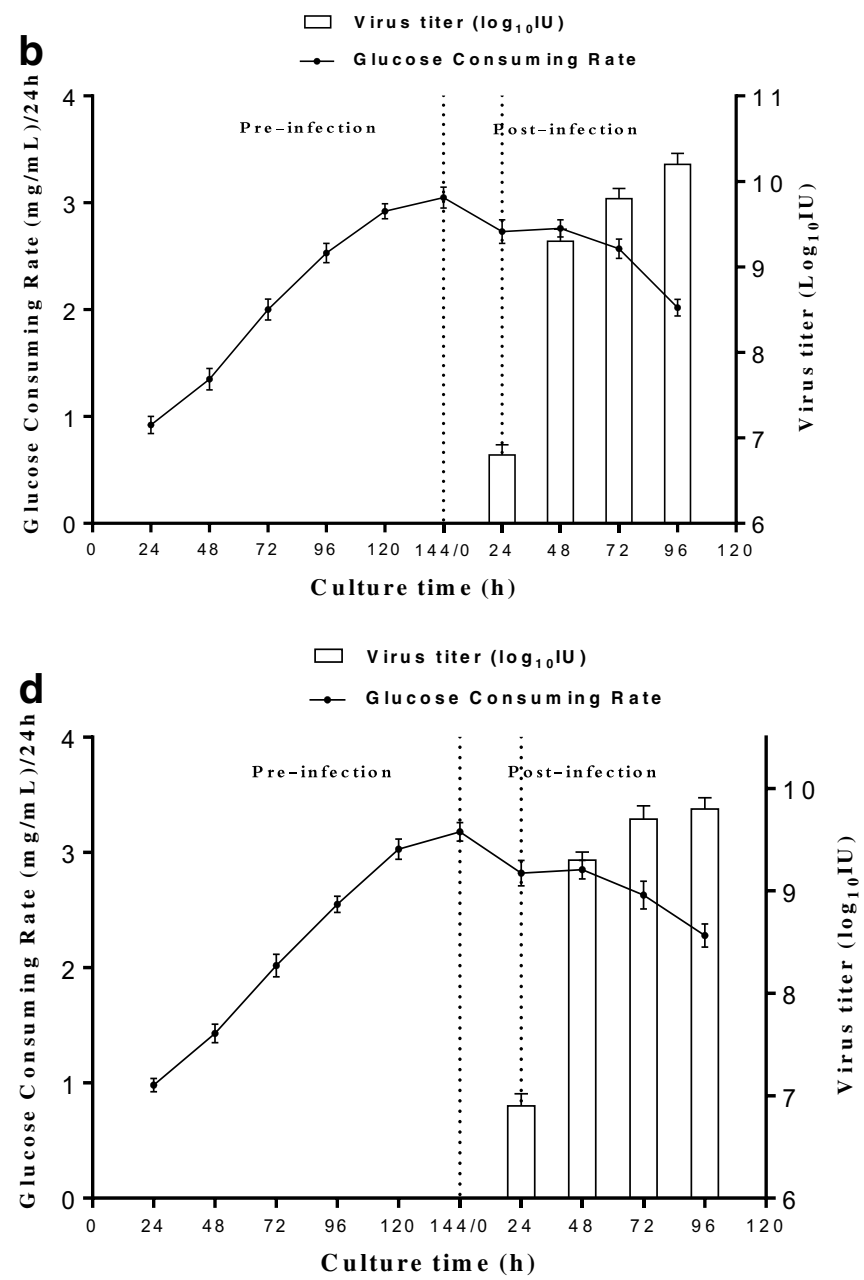

P1 strategy. $\mathbf{c}$ The GCR and viral titer in the ACPB-2, 3, and 4 runs using the P4 (25\% LH) strategy. d The GCR and viral titer in the NBSBioflo310 run using the $\mathrm{P} 4(0.25 \% \mathrm{LH})$ strategy

LH) supplementation strategy compared with P1 strategy (Table 2).

The specific activity of Ad5 vector harvested from the $\mathrm{ACPB}$ and Bioflo310 was calculated. The results show that the specific activity of Ad5 from the ACPB-2/P4 and Bioflo310/P4 is higher than from ACPB-1/P1 (Table 3). The specific activity of Ad5 from cell lysates is much lower than that from supernatants. The Ad5 product was fully characterized by a number of chemical and biological tests (Table 4). The results indicated that the quality of Ad5 was in compliance with GMP standard.
Table 2 Residual bovine serum albumin in supernatants following different supplementation approaches

\begin{tabular}{llll}
\hline Source & Harvest time & \\
\cline { 2 - 4 } & $48 \mathrm{hpi}$ & $72 \mathrm{hpi}$ & $96 \mathrm{hpi}$ \\
\hline ACPB-1/P1 & $3.0 \times 10^{7} \mathrm{ng} / \mathrm{mL}$ & $4.6 \times 10^{7} \mathrm{ng} / \mathrm{mL}$ & $3.8 \times 10^{7} \mathrm{ng} / \mathrm{mL}$ \\
ACPB-2/P4 (0.25\% LH) & $680 \mathrm{ng} / \mathrm{mL}$ & $185 \mathrm{ng} / \mathrm{mL}$ & $46 \mathrm{ng} / \mathrm{mL}$ \\
Bioflo310/P4 (0.25\% LH) & $560 \mathrm{ng} / \mathrm{mL}$ & $134 \mathrm{ng} / \mathrm{mL}$ & $32 \mathrm{ng} / \mathrm{mL}$ \\
\hline
\end{tabular}


Table 3 Specific activity of Ad5 vector harvested from the ACPB and NBS-Bioflo310

\begin{tabular}{lll}
\hline Specific activity (\%) & $\begin{array}{l}\text { Supernatant } \\
\text { (extracellular) }\end{array}$ & $\begin{array}{l}\text { Cell lysates } \\
\text { (intracellular) }\end{array}$ \\
\hline ACPB-1/P1 & $3.8 \%$ & $2.8 \%$ \\
ACPB-2/P4 (0.25\% LH) & $5.8 \pm 0.8 \%$ & $3.6 \pm 0.3 \%$ \\
Bioflo310/P4 (0.25\% LH) & $6.1 \%$ & $3.8 \%$ \\
\hline
\end{tabular}

\section{Discussion}

Although the production of Ad has been investigated in a number of publications and reviewed (Bewig and Schmidt 2000; Whitfield et al. 2009), it remains challenging to significantly improve product yields to reduce the cost of goods and maintain economic viability. Maximization of virus particle yields and stability of active vector during the course of production will certainly rely on a better understanding of key replication mechanisms and kinetic parameters (Maranga et al. 2005; Nadeau et al. 2000; Petiot et al. 2011; Siegwart et al. 1999). A suitable medium replacement strategy is a crucial factor for successful manufacturing of Ad vectors. Medium is the main cost of production and also has an important influence on downstream processes and the quality of final products. During the initial 0-24 hpi in a bioreactor, Ad5 titers are below $10^{6} \mathrm{IU}$ and are barely amplified. The $24-\mathrm{h}$ infection period allows for entry of the Ad into 293 cells and for expression of GFP; however, no secondary infection occurs within the 24-h post-infection period. During this period, cells infected with virus consume more nutrients in the medium. The decrease in productive infection at a high cell density is called the "cell density effect" (Kamen and Henry 2004; Nadeau and Kamen 2003). In order to maintain cell viability and overcome nutrient limitations and the cell density effect, we used DMEM supplemented with 10\% FBS for the first $24 \mathrm{~h}$ post-infection and then replaced the medium with DMEM supplemented with $0.25 \%(w / v)$ LH and glucose $(2 \mathrm{mg} / \mathrm{mL})$ at $24-\mathrm{h}$ intervals. This approach provided the cells with a sufficient nutrient stock for the subsequent $72 \mathrm{~h}$ for virus production. The advantages of this protocol are its low cost, high yield, and lower levels of residual serum.
The mini-bioreactor is a new tool for cell culture, which is characterized by small size and ease of operation. The minibioreactor offers a very rapid process to create cell banks and virus seeds. The ACPB system provides a high oxygen transfer efficiency and reduces the shearing force of bubbles, which makes it very suitable for virus culture. In the $\mathrm{ACPB}$, the bioreactor bag and perfusion column are constructed with presterilized plastic. This design eliminates the need for cleaning and sterilization, and, therefore, shortens the implementation time to conform to GMP. Additionally, the ACPB can be scaled up to $300 \mathrm{~L}$ with a larger perfusion column and bioreactor bag.

It is well documented that the MOI is a key factor in $\mathrm{Ad}$ vector infection. When cells are infected at an MOI greater than 20, a synchronous infection occurs (Nadeau and Kamen 2003). Since cells are not accessible during the culture period, an indirect method for estimating cell density in this system was developed. In this study, GCR was used as an indirect indicator to estimate cell growth and density in mini-bioreactors to study the relationship between cell density and GCR. The results showed that GCR is a reliable estimation of cell density growth in this model system (Meuwly et al. 2006; Yang and Butler 2000). It has been reported that temperature significantly affects cell metabolism, with extended viability being favored at low temperatures. The effect of temperature on viral production is significant. In this study, we found that maximum viral production occurred at $35^{\circ} \mathrm{C}$, which is consistent with previous studies (Jardon and Garnier 2003).

Specific activity of recombinant Ad is a very crucial factor that may affect whether the Ad5 vector-related products can progress to clinic trial. According to SFDA standards, the specific activity of recombinant Ad clinical products should be greater than $3.3 \%$. The bioactivity of Ad5 vectors can be affected by the purity of the harvest and the downstream purification process. In our study, the increase in specific activity may be attributable to using a relatively "serum-free" strategy and discarding the intracellular virus.

In summary, we established a novel model system and suitable culture strategy for Ad5 vector production. This model system offers a rapid and economical process to produce GMP-level Ad5 products, which may shorten the research period leading to clinic trial.
Table 4 Inspection report for quality control of Ad5 vector harvested from the $\mathrm{ACPB} / \mathrm{P} 4$ and $\mathrm{ACPB} / \mathrm{P} 1$

\begin{tabular}{llll}
\hline Test items & Quality standard & ACPB/P4 & ACPB/P1 \\
\hline RCA & $<1 \mathrm{RCA} / 3 \times 10^{10} \mathrm{VP}$ & $<1 \mathrm{RCA} / 3 \times 10^{10} \mathrm{VP}$ & $<1 \mathrm{RCA} / 3 \times 10^{10} \mathrm{VP}$ \\
AAV detection & Negative & Negative & Negative \\
Sterility testing & Negative & Negative & Negative \\
Mycoplasma & Negative & Negative & Negative \\
Endotoxin testing & $<10 \mathrm{EU} / \mathrm{mL}$ & 2.4 & 3.9 \\
\hline
\end{tabular}


Acknowledgments We would like to thank AmProtein (Hangzhou, China) for their assistance with ACPB photos. We also thank the native English speaking scientists of Elixigen Company (Huntington Beach, California) for editing our manuscript.

Funding This work was supported by the State Project of Essential Drug Research and Development (grant number 2015ZX09101044) and the Science \& Technology Key Program of Zhejiang, China (grant number 2014C03039)

\section{Compliance with ethical standards}

This article does not contain any studies with human participants or animals performed by any of the authors.

Conflict of interest The authors declare that they have no conflicts of interest.

\section{References}

Bewig B, Schmidt WE (2000) Accelerated titering of adenoviruses. Biotechniques 28(5):870-873

Cote J, Bourget L, Garnier A, Kamen A (1997) Study of adenovirus production in serum-free 293SF suspension culture by GFPexpression monitoring. Biotechnol Prog 13(6):709-714. https:// doi.org/10.1021/bp970110i

Green M, Wold WS (1979) Human adenoviruses: growth, purification, and transfection assay. Methods Enzymol 58:425-435

Guan YS, Liu Y, Zhou XP, Li X, He Q, Sun L (2006) p53 gene (Gendicine) and embolisation overcame recurrent hepatocellular carcinoma. Gut 55(11):1684. https://doi.org/10.1136/gut.2006. 069237

Hui M (2007) AmProtein corporation. A method to increase dissolved oxygen in a culture vessel. In: International patent \#WO2007/ 142664

Iyer P, Ostrove JM, Vacante D (1999) Comparison of manufacturing techniques for adenovirus production. Cytotechnology 30(1-3): 169-172. https://doi.org/10.1023/A:1008040221630

Jardon M, Garnier A (2003) PH, pCO2, and temperature effect on Radenovirus production. Biotechnol Prog 19(1):202-208. https:// doi.org/10.1021/bp025585a

Kamen A, Henry O (2004) Development and optimization of an adenovirus production process. J Gene Med 6(Suppl 1):S184-S192. https://doi.org/10.1002/jgm.503

Li L, Shi M, Song Y, Bao L, Yang W, Zhang X, Ruan M, Rishton G, Joudi A, Teng Y, Xing Y, Hu F, Zhao X, Zhang X, Li H, Leng G, Yuan S, Jia Q, Hui M (2009) A single-use, scalable perfusion bioreactor system. Bioprocess Int 7(6):46-54

Liu H, Liu XM, Li SC, Wu BC, Ye LL, Wang QW, Chen ZL (2009) A high-yield and scaleable adenovirus vector production process based on high density perfusion culture of HEK 293 cells as suspended aggregates. J Biosci Bioeng 107(5):524-529. https://doi.org/10. 1016/j.jbiosc.2009.01.004

Lusky M (2005) Good manufacturing practice production of adenoviral vectors for clinical trials. Hum Gene Ther 16(3):281-289. https:// doi.org/10.1089/hum.2005.16.281
Maranga L, Aunins JG, Zhou W (2005) Characterization of changes in PER.C6 cellular metabolism during growth and propagation of a replication-deficient adenovirus vector. Biotechnol Bioeng 90(5): 645-655. https://doi.org/10.1002/bit.20455

Meuwly F, Papp F, Ruffieux PA, Bernard AR, Kadouri A, von Stockar U (2006) Use of glucose consumption rate (GCR) as a tool to monitor and control animal cell production processes in packed-bed bioreactors. J Biotechnol 122(1):122-129. https://doi.org/10.1016/j.jbiotec. 2005.08.005

Nadeau I, Kamen A (2003) Production of adenovirus vector for gene therapy. Biotechnol Adv 20(7-8):475-489

Nadeau I, Jacob D, Perrier M, Kamen A (2000) 293SF metabolic flux analysis during cell growth and infection with an adenoviral vector. Biotechnol Prog 16(5):872-884. https://doi.org/10.1021/bp0000981

Petiot E, Jacob D, Lanthier S, Lohr V, Ansorge S, Kamen AA (2011) Metabolic and kinetic analyses of influenza production in perfusion HEK293 cell culture. BMC Biotechnol 11:84. https://doi.org/10. 1186/1472-6750-11-84

Qian J, Li H, Hui M, Hui N, Rishton AJG, Bao L, Shi M, Zhang X, Luanfeng L, Xu J, Leng G (2008) A bioreactor system based on a novel oxygen transfer method. Bioprocess Int 6(6):66-78

Schoofs G, Monica TJ, Ayala J, Horwitz J, Montgomery T, Roth G, Castillo FJ (1998) A high-yielding serum-free, suspension cell culture process to manufacture recombinant adenoviral vectors for gene therapy. Cytotechnology 28(1-3):81-89. https://doi.org/10.1023/A: 1008021428969

Sharon D, Kamen A (2018) Advancements in the design and scalable production of viral gene transfer vectors. Biotechnol Bioeng 115(1): 25-40. https://doi.org/10.1002/bit.26461

Shen CF, Lanthier S, Jacob D, Montes J, Beath A, Beresford A, Kamen A (2012) Process optimization and scale-up for production of rabies vaccine live adenovirus vector (AdRG1.3). Vaccine 30(2):300-306. https://doi.org/10.1016/j.vaccine.2011.10.095

Siegwart P, Cote J, Male K, Luong JHT, Perrier M, Kamen A (1999) Adaptive control at low glucose concentration of HEK-293 cell serum-free cultures. Biotechnol Prog 15(4):608-616. https://doi. org/10.1021/Bp990077v

Singh V (1999) Disposable bioreactor for cell culture using wave-induced agitation. Cytotechnology 30(1-3):149-158. https://doi.org/10. 1023/A:1008025016272

Sun B, Yu XH, Kong W, Sun SY, Yang P, Zhu CL, Zhang HH, Wu YG, Chen Y, Shi YH, Zhang XZ, Jiang CL (2013) Production of influenza H1N1 vaccine from MDCK cells using a novel disposable packed-bed bioreactor. Appl Microbiol Biotechnol 97(3):10631070. https://doi.org/10.1007/s00253-012-4375-7

Whitfield RJ, Battom SE, Barut M, Gilham DE, Ball PD (2009) Rapid high-performance liquid chromatographic analysis of adenovirus type 5 particles with a prototype anion-exchange analytical monolith column. J Chromatog A 1216(13):2725-2729. https://doi.org/10. 1016/j.chroma.2008.11.010

Yang M, Butler M (2000) Enhanced erythropoietin heterogeneity in a $\mathrm{CHO}$ culture is caused by proteolytic degradation and can be eliminated by a high glutamine level. Cytotechnology 34(1-2):83-99. https://doi.org/10.1023/A:1008137712611

Zhang WW, Li L, Li D, Liu J, Li X, Li W, Xu X, Zhang MJ, Chandler LA, Lin H, Hu A, Xu W, Lam DM (2018) The first approved gene therapy product for cancer Ad-p53 (Gendicine): 12 years in the clinic. Hum Gene Ther 29(2):160-179. https://doi.org/10.1089/ hum. 2017.218 